\title{
CHEMISTRY OF ARBORININE AND PHARMACOLOGICAL ACTIVITIES
}

Ernestine Nkwengoua Tchouboun Zondegoumba ${ }^{a, b, c *}$, Whistler Lucain Dibahteu Tankoua ${ }^{a}$, Olivier Eteme Ndogo ${ }^{a}$, Barthelemy Nyasse ${ }^{a}$, Rodrigo Santos ${ }^{b}$, Francisco Jaime Bezerra Mendonça Junior ${ }^{b, c}$, Luciana Scotti ${ }^{c}$, Marcus Tullius Scotti ${ }^{c}$, Maria do Carmo Alves de Limad

a Laboratory of Medicinal Chemistry, Department of Organic Chemistry, Faculty of Science, University of Yaounde l; 812, Yaounde, Cameroon,

${ }^{b}$ Laboratory of Synthesis and Drug Delivery; State University of Paraiba-Campus 1; 58051-970, Joǎo Pessoa, Brazil

${ }^{c}$ Postgraduate Program in Natural and Synthetic Bioactive Products. Federal University of ParaibaCampus V; 58071-760, Joăo Pessoa, Brazil

${ }^{d}$ Department of Antibiotics, Research Group in Therapeutic Innovation, Federal University of Pernambuco, 50670-901 Recife, PE, Brazil

*Correspondance: Phones: (237) 69162545; (5583) 998271766; E-mail: ernestine.nkweng@gmail.com.

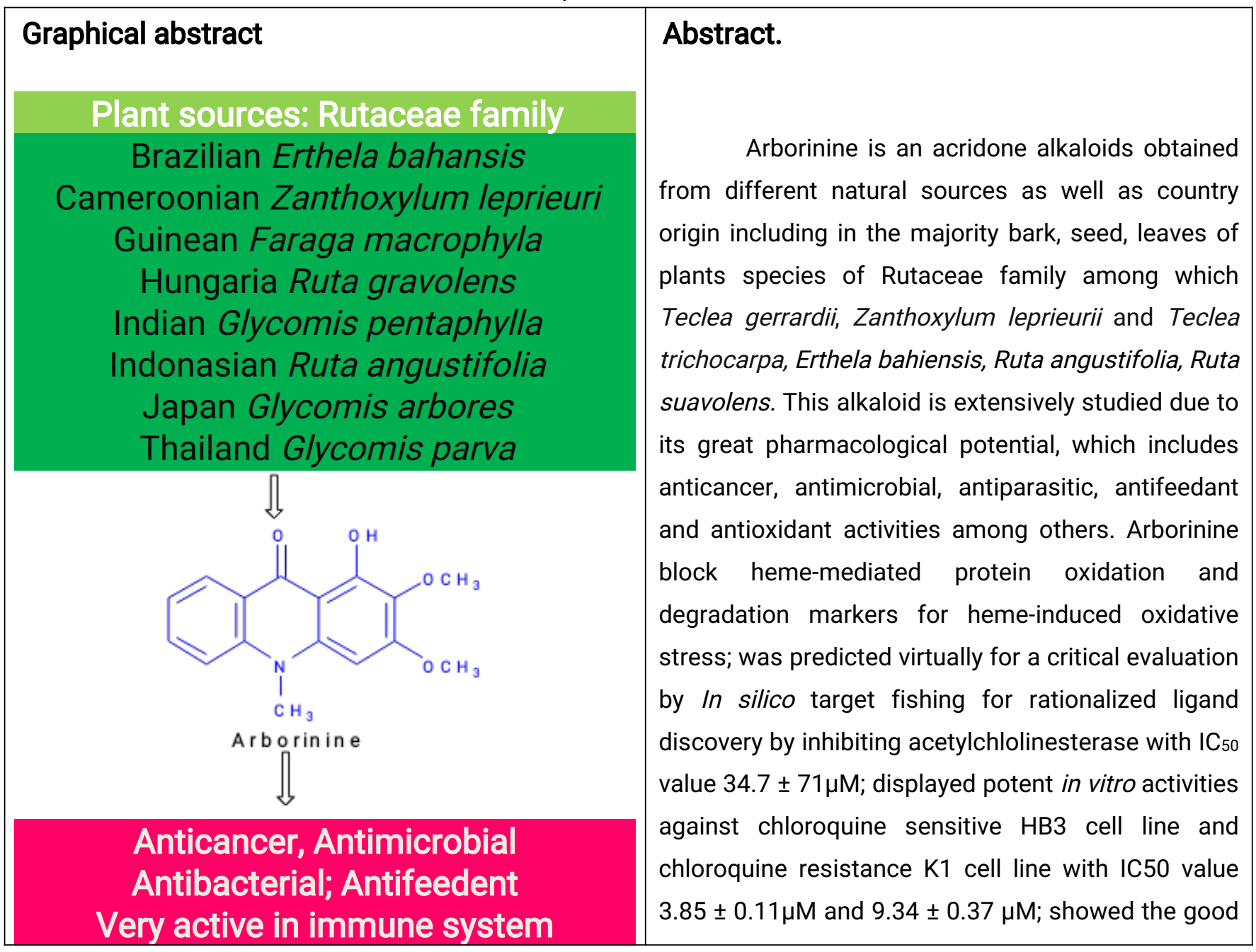




\begin{tabular}{|l|l|}
\hline & $\begin{array}{l}\text { anticancer activity on three human cancer line viz } \\
\text { human colon cancer COLO-205, human ovarian } \\
\text { cancer OVCAR-3, Human cervical cancer human } \\
\text { breast cancer and T-47D line with Glso value } \\
<10 \mu \mathrm{g} / \mathrm{ml} \text { and presented antimicrobial activities } \\
\text { against resistant microbial strains. The overall } \\
\text { synthesis of Arborinine has been done and the key } \\
\text { stapes are the Ullmann condensation followed by the } \\
\text { cyclisation with Eaton's reagent. It undergoes a few } \\
\text { structural modification reactions such as selective } \\
\text { methylation and demethylation, electrophilic } \\
\text { substitution. Acetylation, benzoylation. This review } \\
\text { present the chemistry and the biological properties } \\
\text { of Arborinine: methods of isolation from plant crude } \\
\text { extract, its characterization as well as their } \\
\text { derivatives obtained by structural modification } \\
\text { including structure activity relationship are also } \\
\text { described. }\end{array}$ \\
$\begin{array}{l}\text { Keywords: Arborinine; Natural Product; Acridone } \\
\text { alkaloids; country; Synthesis; Anticancer, } \\
\text { Antimicrobial, Antiparasitic, Antifeedant. Structure } \\
\text { Activity Relationship (SAR). }\end{array}$ \\
\hline
\end{tabular}

\section{Introduction.}

Arborinine is a tricyclic ring having an N-Methylatated nitrogen at tenth position a keto group at the ninth position with a substituted hydroxyl group, two methoxyl at the position one, two and tree respectively. This compound belongs to the Acridone class, one of the important pharmaceutical group of heterocyclic compounds named Alkaloid (Michel, J.P et al., 2001). Arborinine has been isolated in numerous natural plants (Teclea gerrardii, Zanthoxylum leprieurii and Teclea trichocarpa, Erthela bahiensis, Ruta angustifolia, Ruta suavolens, Glycomis arbores, Glycomis pentaphylla) from many countries (Brazil, Cameroon, Guiney, Hungary, India, Indonesia, Japan, and Thailand) and his synthesis has been also described Belmont, P. et al, 2007; Ramesh Kumar, 2011; Rajesh Kumar et al., 2018) as well as his possible derivatives. The reduction of the carbonyl group can increase the number of synthetic routes available (Rajesh Kumar et al., 2018) for any desired acridine 
derivatives which are also valuable in term of lead compounds. Its exceptional diverse biological activities have attracted attention of chemists and biologist. Among his numerous pharmacological effects, Arborinine is most potent as anticancer, antimicrobial, antifeedant, antimalarial, antioxidant, against immune system cells. His structure is planar as other acridone

alkaloids it is act on nucleotides in one hand by inducing DNA damageindependent apoptosis and emerging as strong potent anticancer agent; in other hand, it interfered by an inhibitory manner preferentially on the death of the cells under mitogenic stimulation and this give ride to a very good effect in the immunesystem cells.

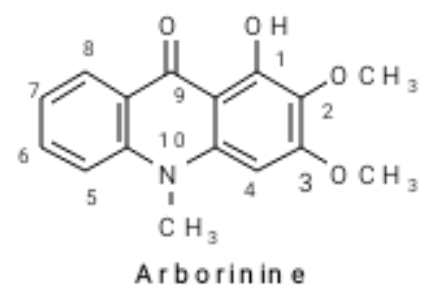

\section{Chemistry of Arborinine}

Arborinine is a yellow needless compound, m.p. $175-176^{\circ} \mathrm{C}$ and gives a deep green coloration with alcoholic ferric chloride (Banerjee, S.K., 1961). Its crystal X-ray structure has been publish in 2017. It was found to have the molecular formula $\mathrm{C}_{16} \mathrm{H}_{16} \mathrm{O}_{4} \mathrm{~N}$. It was found to be optically inactive (Chakravarti et al., 1953, Banerjee S.K. et al., 1961). The nomenclature adopted by Chemical Abstract in 1937 is the one of Graebe (1893) based on the same system used for anthracene and Xanthene; then synonyms of Arborinine are 1-hydroxy-2,3-dimethoxy-N-Methyl 9(10H)-acridone, 1-, similar to the compound describe in 1952 by Hughes G.K. et al. (Banerjee S.K. et al., 1961). , hydroxy-2,3-dimethoxy-N-Methylacridine-9-one, 1-hydroxy-2,3-dimethoxy-NMethyl-9-acridone...etc.

Arborinine can also be obtained by synthesis. Although many review and articles detailed the synthesis of acridone alkaloid skeleton, few reports have been conducted regarding the overall synthesis of Arborinine (Phylipe Belmont et al, 2007; Ramesh Kumar, 2011; Rajesh Kumar et al., 2018). The key stapes are the Ullmann condensation followed by the cyclisation (scheme1, a) with Eaton's reagent or modified methods scheme1 b, b' e). (See scheme 1).

\section{Scheme1: Synthesis pathway of Arborinine}




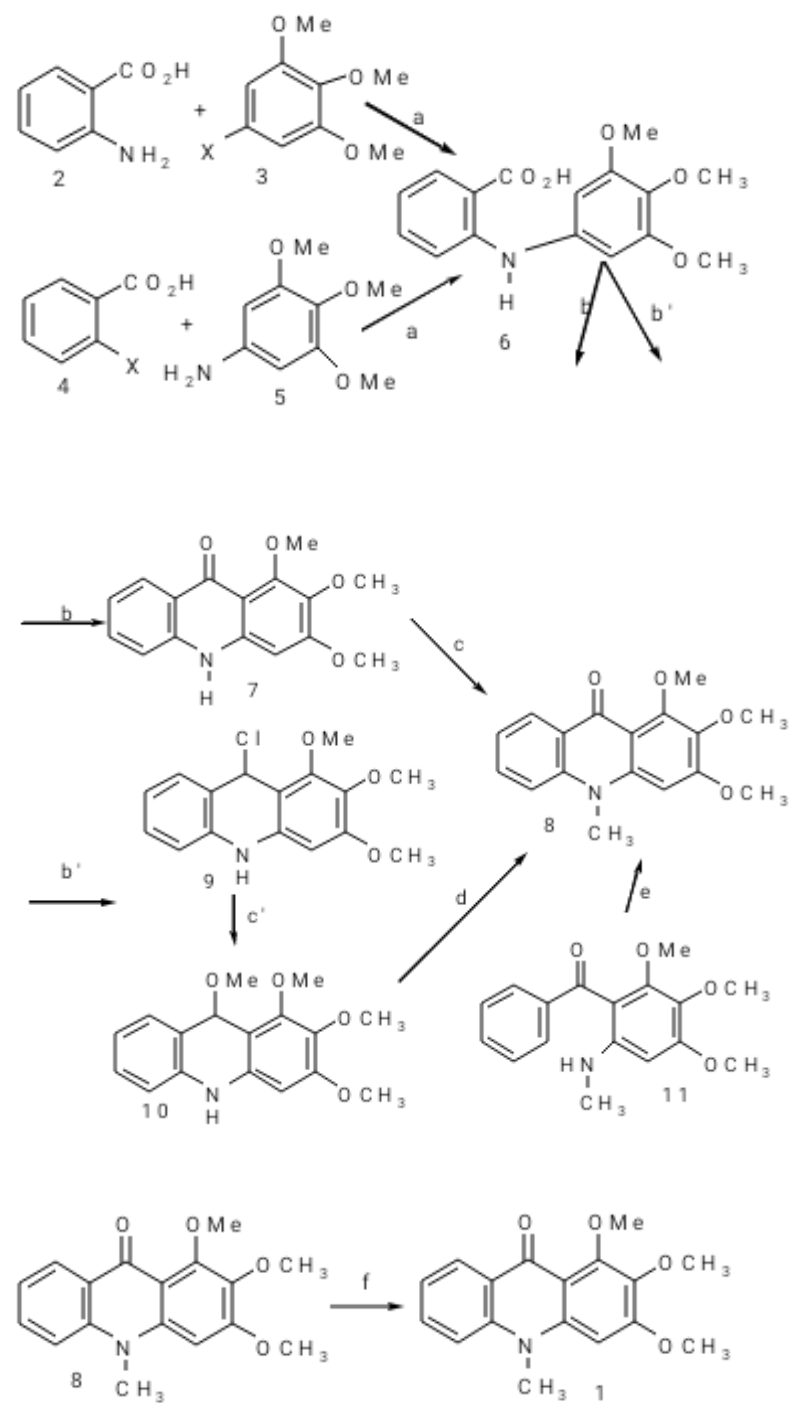

\footnotetext{
a: U llm ann condensation: $\mathrm{CU}_{2} \mathrm{O}, \mathrm{K}_{2} \mathrm{CO}_{3}$, diglyme, $64 \%$

b: cyclisation: $\mathrm{P}_{2} \mathrm{O}_{3}-\mathrm{CH}_{3} \mathrm{SO}_{3} \mathrm{H}, 65 \%$

b': cylisation: $\mathrm{POCl}_{3}$ (exces), 235-145m in, $3 \mathrm{~h}$

C: Methylation $\mathrm{NaH}, \mathrm{Mel}, \mathrm{THF}, 85 \%$

$c^{\prime}$ : S N 2: NaO Me/MeOH, reflux,

$d^{\prime}:$ oxydation and methylation: Mel, Scaled tube, $100^{\circ} \mathrm{C}, 4 \mathrm{~h}$

e: CUI, $\mathrm{O}_{2}, \mathrm{MeCONH}, 160^{\circ} \mathrm{C}, 12 \mathrm{~h}$ )

f: Selective demethylation: E TO H, HCI reflux, $80 \%$ scheme 2). and can undergoes a few structural modification reactions such as selective methylation and demethylation, electrophilic substitution, acetylation and benzoylation according to one active hydrogen in position 1 The reduction of the carbonyl group can also increase the number of synthetic routes available for any desired acridine derivatives which are the valuables structures for many potent drugs. 


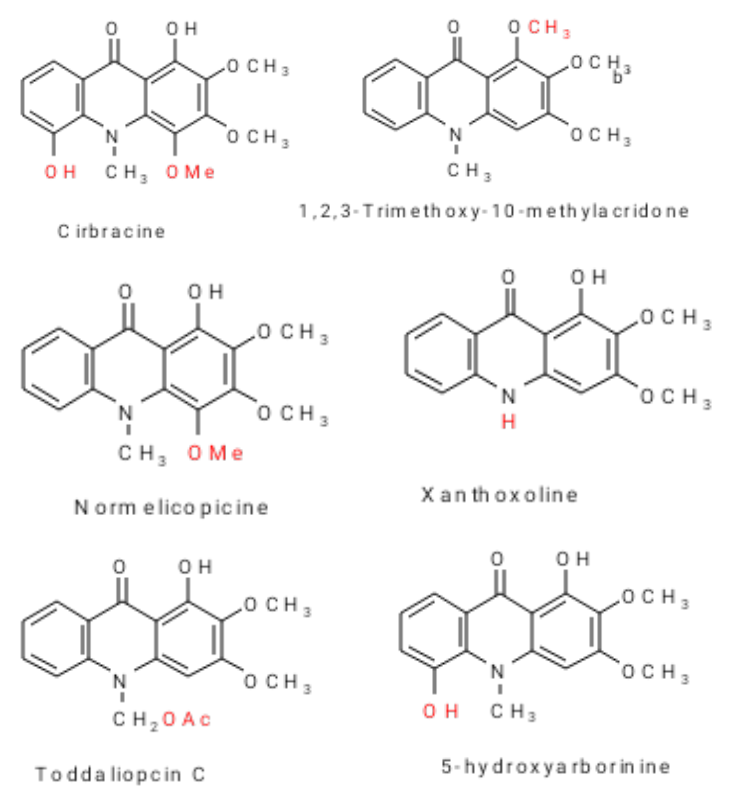

\section{Scheme2: Structure some derivatives of} Arborinine

\section{Biological Activities}

In 2013, Onguéné, A. et al. published a review on the pharmacological evaluation of alkaloids and terpenoids compounds derived from African medicinal plants against three Plasmodium falciparum strains: chloroquine susceptible, CQS strains named 3D7, chloroquine sensitive HB3 and chloroquine resistance K1 strains. Results showed that among the most promising anti-plasmodial acridones alkaloids derived from the African flora, the best compound was Arborinine obtained from Teclea gerrardii, Zanthoxylum leprieurii and Teclea trichocarpa (Rutaceae). Arborinine showed a good activity against chloroquine susceptible, CQS strains named 3D7 with IC 50 value of $4.5 \mu \mathrm{gmL}^{-1}$ [Amoa Onguéné et al., 2013]. This acridone alkaloid displayed potent in vitro activities against chloroquine sensitive HB3 cell line and chloroquine resistance $\mathrm{K} 1$ cell line with $\mathrm{IC}_{50}$ value $3.85 \pm 0.11 \mu \mathrm{M}$ and $9.34 \pm 0.37$ $\mu \mathrm{M}$. This molecule did not show cross resistance with chloroquine. Nevertheless, these values were relatively weak compared to chloroquine: Arborinine found to be 15-fold less active than chloroquine against strain K1 and 140-fold less active than chloroquine against strain HB3. In addition, Natural Arborinine from commercial source had been evaluated in vitro against $P$. falciparum isolated by Astelbauer, F. et al. in 2002, and showed poor activity characterized by $\mathrm{IC}_{50}$ and $\mathrm{IC}_{99}$ value higher than $350 \mu \mathrm{M}$ and $180 \mu \mathrm{M}$ respectively compared to the drug reference Artemicine.

As far as the Structure activity relationship (SAR) is concerning, other studies have revealed new promising antiplasmodial compounds based on acridone core with $\mathrm{N}$-Me group; 
moreover, 1-hydroxy group is essential for the activity and the presence of a methoxy group at the position 4 of Arborinine decreased the activity (Mary W. Muriithi et al. 2002) whereas 2nitro substituted increased the activity (Basco et al., 1994).

Regarding the mechanism of action, diverse mechanism have been proposed for the antimalarial activity of acridones as well as Arborinine, including: inhibition of Hemozoin ( $\beta$ hematin) formation, mitochondrial $b c$, complex with DNA and topoisomerase II, and interaction with DNA are the widest studied (Valdès, A.F.-C. , 2011).

In vitro assessment and evaluation of Arborinine from Brazilian Erthela baihensis in immune-system cells stimulated with various mitogens with cultured rat thymus and spleen cells has been performed by Roseghini, R. et al in 2006: this acridone alkaloid interfered by an inhibitory manner preferentially, on the proliferation and death of cells under mitogenic stimulation and did not induce necrosis on this cell. These studies and elucidation of Arborinine action mechanisms on cellular activation and death pathways as well as identification of cell subpopulations under effect of Arborinine could open new perspectives for the use of this drug ( Roseghini, R. et al in 2006).

The decoction extract of Indian Glycocmis pentaphylla showed moderated DPPH radical scavenging property $\left(\mathrm{IC}_{50} 182.21 \mu \mathrm{M}\right)$; when compare to the standard, It prescribed as a save natural antioxidant source compared to the synthetic antioxidants BHT and BHA. The oxidative stress has a link with the immune system, tumor or inflammation (Roseghini, R. et al). This indication corroborate with the results of of Kitiya P.et al, 2018 on another species of Thailand, Glycomis parva leaf extract contained Arborinine, which has been isolated and showed a strong inhibition against cancer cervical cells. His cytotoxicity was more pronounced against HeLa than normal cells and was much more potent at inhibiting tumor spheroid growth than commonly used chemotherapeutic drugs; it can induce DNA damageindependent apoptosis and inhibit cancer cell. Arborinine could be proposed to serve as an alternative drug to Cisplatin for treatment of cervical cancer. Previously, Micheal, J. P. in 2017 had already assessed Arborinine from chemical natural library for his strongand good activity on COLO-205, OVCAR-3 and T-47D with Gl $1_{50}$ value $<10 \mu \mathrm{g} / \mathrm{ml}$, compared against a standard anticancer drug Adriamycin. The strong activity of Arborinine on other 20 cell line has been reviewed and reported.

Despite the few antifungal and antiviral activity that have been reported for Arborinine, Antibacterial activity is the most common type of antimicrobial activity inventoried. Arborinine isolated Indonesian Ruta angustifolia was found to disrupt human rhinovirus 
serotype 2 (HRV-2) coat protein on infected HeLa cells $\left(\mathrm{IC}_{50} 3.19 \pm 2.24 \mu \mathrm{M}\right)$, although the $50 \%$ toxic concentration was more than $50 \mu \mathrm{M} / \mathrm{mL}$. This compound also inhibited the replication of hepatitis $\mathrm{C}$ virus (genotype $2 \mathrm{a} \mathrm{J} 6 / \mathrm{JFH} 1$ ) in human hepatoma Huh7.5 cells (IC $\mathrm{C}_{50} 6.4 \pm 0.7 \mu \mathrm{M}$ ), with the $50 \%$ toxic concentration $16.3 \pm 6.2 \mu \mathrm{M} / \mathrm{mL}$. (Wahyuni, T.S. et al,). Arborinine showed mild to moderate antimicrobial activity against Staphylococus aureus, Klebsiella pneumonia, Bacillus subtilis and Candida albicans strains in Agar well diffusion method (Das, M. M. et al., 2018, Fouotsa ,H. el al. 2013); other reported results on positive and negative grams bacteria's strains has been done by Michael, J.P. in 2017. This compounds also inhibited acetylchlolinesterase with $\mathrm{IC}_{50}$ value $34.7 \pm 71 \mu \mathrm{M}$ (Michael J. P., 2017). The one from Guinean Fagara macrophylla was tested to be effective antifeedant towards final stage larval of the lepidopteron pest Spedoptera frugiperda (fall army worm). (Ntie-Kang, F. et al, 2014).

\section{Conclusion}

Arborinine is a biomolecule that can be obtained from as well natural as synthetic sources. His structure has two main functional groups (carbonyl and hydroxyl) which suitable for many hemi-synthesis reactions giving varied derivatives valuable for lead compounds. Arborinine interfered by an inhibitory manner preferentially, on the proliferation and death of cells under mitogenic stimulation and did not induce necrosis on this cell. In addition, Arborinine can induce DNA damage-independent apoptosis and inhibit cancer cell; then, Arborinine could be proposed to serve as an alternative drug to Cisplatin for treatment of cervical cancer. This acridone alkaloid could then be classified as multitarget drug; the knowledge of his Cristal X-ray Structure open new perspectives for the design so many inhibitors, thus coud open new perspectives for the development of this drug .

\section{References}

Astelbauer, $\quad$ F.; Gruber, M.; Brem, B.; Greger, H.; Obwaller, A.; Wernsdorfer, G.; Congpuong, K.; Wernsdorfer, W.H.; walochnik, J. Activity of selected Phytochemicals against Plasmodium falciparum. Acta Tropica, 2012, 123, 96-100.

Banerjee, S.K.; Chakravarti, D.; Chakravarti, R.N.; Flales H.M.; Klaymann D.L. Alkaloids of Glycosmis arborea - III. Structure of Arborinine. Tetrahedron, 1961, 16, 251-254.

Chakravarti D.; Chakravarti R.N.; Chakravarti S.CAlkaloids of Glycosmis arborea Part I. Isolation o and Arborine and Arborinine: The structure of Arborine. 1953, 3337-3338. View on line/

Fouotsa, H.; Mbaveng, A.T.; Mbazoa, C.D.; Nkengfack, A. E.; Farzana, S.; Iqbal, C. M. ; Meyer, J.J .M.; Lall, N.; Kuete, V. Antibacterial constituents of three Cameroonian medicinal plants: Garcinia nobilis, Orica 
suaveolens and Balsamocitrus camarunensis. BMC complementary and Alternative Medicine, 2013, 13: 81-

Michael, J. P. Quinoline, quinazoline and acridone lkaloids. Nat. Prod. Rep., 2001, 18, 543-559.

Michael, J. P. Chapter one: Acridone Alkaloids-Secret of life. The Alcaloids, Volume 78, Elsevier, 2017, 1107

Kitiya, P., Phattharachanok, K.; Mattaka, K., Teerapong ,Y.; Nijsiri, R.; Chaisak, C.; Tawin ,I. Anticancer activity of arborinine from Glycosmis parva leaf extract in human cervical cancer cells. Biochemical and Biophysical Research Communications, 2018, xxx, 1-7

Muriithi, M.W.; Kendrick, H.; Abraham, W.-R. ; Njagi, E. N. M.; Addae-Kyereme, O. J. ; Wright, C.W. ; Scowen, I. ; Croft, S. L.; Gitu, P. M.. Isolation and in vitro antiplasmodial activities of alkaloids from teclea trichocarpa: in vivo antimalarial activity and X-ray crystal structure of Normelicopicine. J. Nat. Prod. 2002, 65, 956-959.

Das M.M. \& Deka, D.C. Evaluation of Anticancer and Antimicrobial Activity of Arborinine from Glycosmis pentaphylla, Journal of Biologically Active Products from Nature, 2017, 7(2), 131-139.

Ntie-Kang, F., Lifongo, L. L. ; Simoben, C. V. ; Babiaka, S. B. ; Sippl W. ; Mbaze L. M.. The uniqueness and therapeutic value of natural products from West African medicinal plants, part I: Uniqueness, Chemotaxonomy RSC Adv., 2014, DOI: 10.1039/C4RA03038A.

Onguéné, P. A.; Ntie-Kang, F.; Lifongo, L. L.; Ndom, J.C.; Sippl, W.; Mbaze, L M. The potential of antimalarial compounds derived from African medicinal plants, part l: a pharmacological evaluation of alkaloids and terpenoids. Malaria Journal, 2013, 12:449 http://www.malariajournal.com/content/12/1/449

Roseghini, R.; Moreira, P. ; Vale, V. ; Pinheiro, A.M.; Costa, J.F.O.; Bittencourt, T. ; Nascimento, I. ; Schaer, R. ; Velozo, E.; El-Bachá, R.; Meyer , R.; Freire., S. Different effects of Arborinine alkaloid obtained from Brazilian Erthela baihensis on Spleen and Thymus cells stimulated in vitro with different mitogens. Immunopharmacology and Immunotoxicology, 2006, 28, Issue 2, 361-376: https://doi.org/10.1080/08923970600809579

Chandran, R. \& Parimelazhagan, T. Evaluation of total phenolics and free radical quenching activity of Glycosmis pentaphylla (RETZ.) A. DC. Diabetes Mellitus and Human Health Care. Chapter 3, Academic Press; 171-184

Rajesh Kumar, Sarita Sharma, Deonandan Prasad. Key heterocycle cores for designing multitargeting molecules. Chapter 3 Acridones: A relatively lesser explored heterocycle for multifactorial diseases; Book Chapter. 53-132

Wahyuni, T.S.; Widyawaruyanti, A.; IngeLusida, M.; Fuad, A ; Soetjipto, Fuchino, H.; Kawahara, N.; Hayashi, Y.; Aoki, C.; Hotta, H. Inhibition of Hepatitis $\mathrm{C}$ virus replication by chalepin and pseudane IX isolated from Ruta angustifolia leaves. Fitoterapia, 2014, 99, 276-283. 